\title{
A NEW APPROACH TO THE ANALYSIS OF MONETARY POLICY TRANSMISSION THROUGH BANK CAPITAL
}

\author{
María Cantero Sáiz ${ }^{1}$ \\ (canterom@unican.es) \\ Sergio Sanfilippo Azof ra \\ (sanfilis@unican.es) \\ Begoña Torre Olmo \\ (torreb@unican.es) \\ Carlos López Gutiérrez \\ (lopezgc@unican.es) \\ University of Cantabria \\ Avenida Los Castros s/n, 39005 Santander (Cantabria) \\ Spain
}

${ }^{1}$ Corresponding author. 


\title{
A NEW APPROACH TO THE ANALYSIS OF MONETARY POLICY TRANSMISSION THROUGH BANK CAPITAL
}

\begin{abstract}
The purpose of this article is to quantify how bank capital determines the effects of monetary policy on bank lending. Additionally, we test how these effects differ during monetary contractions and expansions. Using a sample of 3,028 European banks between 1999 and 2012, we find that the reduction in loans caused by monetary restrictions is similar across banks regardless of their capital. In addition, during monetary expansions, banks increase their loan supply more as they become better capitalized. Contrary to previous studies, there are differences in the monetary policy transmission through capital only during expansionary monetary regimes. These results are relevant because previous studies have not measured how the marginal effect of monetary policy on the growth of loans varies with the value of capital. We contribute to the existing literature by using a new approach that quantifies this marginal effect, which considerably improves the interpretation of statistical results from models that include continuous variable interactions and allows a better understanding of the role of bank capital in the transmission of monetary shocks.
\end{abstract}

Keywords: Monetary policy; Bank capital; Loan supply; Marginal effect; Continuous variable interaction.

JEL Classification: E44; E52; G21.

\section{Introduction}

The role played by financial institutions is crucial to understanding how monetary policy influences the real economy. In the economic literature and among practitioners, there has been a great interest in analyzing the role of banks in the monetary policy transmission through the bank lending channel. According to this channel, monetary policy impulses, both restrictive and expansionary, alter loan supply by affecting the access of banks to loanable funds (Bernanke and Blinder, 1988). On one hand, a restrictive monetary policy increases the level of required reserves that banks must hold in the Central Bank, which limits the volume of deposits to the availability of reserves (Kashyap and Stein, 1995). In addition, monetary restrictions reduce deposit yields in relation to other assets, thereby reducing households' willingness to hold them (Kishan and Opiela, 2000). Because deposits are an important source of funding for banks, the reduction of the deposit base caused by a monetary restriction will lead them to curtail lending. On the other hand, an expansionary monetary policy alleviates financial frictions and increases the assets that banks have available to lend (Gibson, 1997). Additionally, low interest rates reduce the overall risk portfolio of banks, which induces them to increase loan supply and to loosen credit standards (Maddaloni and Peydro, 2011).

Monetary policy affects not only bank deposits, but also external finance. This fact has led other authors to propose other mechanism for the bank lending channel, owing to the increased use of market-based funding (Disyatat, 2011). Monetary restrictions increase the risk perceptions of banks and deteriorate their balance sheets. This pushes up the cost of market funding for banks, thus leading to a reduction in credit supply. This mechanism has been especially relevant during the crisis because the greater difficulties experienced by banks in getting funding in the financial markets have made lending more sensitive to monetary shocks (Gambacorta and Marques-Ibanez, 2011).

The previously mentioned effects of monetary policy on bank loans vary depending on several variables related to the financial strength of banks. This financial strength was traditionally measured through three indicators: size, liquidity, and capital (Kashyap and Stein, 1995; 2000; Kishan and Opiela, 2000; 2006). Some papers showed market concentration to be another factor that influences the ability of banks to protect their lending from monetary shocks (Adams and Amel, 2011; Olivero et al., 2011). More recently, during the crisis, other papers 
considered banks' credit risk and countries' sovereign risk in the analysis of the bank lending channel (Altunbas et al., 2010; Cantero-Saiz, et al., 2014). In general, these studies showed that banks that are smaller, are less liquid, are more poorly capitalized, have higher credit risk, and operate in less concentrated banking markets and in countries with higher sovereign risk are more sensitive to monetary contractions due to their limited ability to access funding.

Among the variables related to the financial strength of banks, capital has received special attention due to its important role in sustaining lending during the crisis and the new reforms on capital requirements through the adoption of the Basel Accords ${ }^{2}$. During monetary restrictions, banks with lower capital reduce their loan supply more compared with better capitalized banks for two reasons. First, more poorly capitalized banks are more exposed to asymmetric information and moral hazard problems and, thus, are perceived as more risky by market participants. In consequence, these banks find it more difficult and expensive to access external finance (Jayaratne and Morgan, 2000). Second, an increase in the cost of funds, due to a restrictive monetary policy, reduces bank profits and, hence, capital. This causes less capitalized banks to reduce lending to a greater extent to lower the risk of being undercapitalized in the future (Bolton and Freixas, 2006).

Empirical studies in the United States confirmed the idea that lending from lower capitalized banks is more affected by monetary restrictions (Peek and Rosengren, 1995; Kishan and Opiela, 2000; Van den Heuvel, 2002; 2012). Contrary to these studies, which only considered monetary contractions, Kishan and Opiela (2006) reported similar results but also found that monetary expansions were not effective in boosting the lending of less capitalized banks after the adoption of Basel I. Unlike those in the United States, empirical studies in Europe found mixed results on the role of capital in the monetary policy transmission process. On one hand, some papers supported the evidence obtained in the United States during monetary restrictions (Altunbas et al., 2002; Gambacorta and Mistrulli, 2004; Gambacorta, 2005, Jiménez et al., 2012). On the other hand, other studies found that capital does not affect lending from European banks during monetary contractions; probably because there are lower informational asymmetries in Europe than in the United States, banks use their capital to protect themselves against financing problems instead of for lending purposes, and accounting practices during the crisis may have reduced the informative power of capital ratios (Ehrmann et al., 2003; Jimborean, 2009; Gambacorta and Marques-Ibanez, 2011).

One of the shortcomings of the literature on the role of bank capital in the monetary policy transmission is that it focuses on an empirical methodology that relies on categorical variables to construct the capital and monetary policy indicators (Kishan and Opiela, 2000; 2006; Altunbas et al., 2002; Gambacorta and Mistrulli, 2004; Gambacorta, 2005). This means that banks are categorized according to their level of capital (e.g., low or well-capitalized). This approach limits the interpretation of results to the number of categories defined in the empirical specification and does not consider the differences across banks within the same category. Besides, these studies are not highly comparable with each other because they adopt different criteria to define the categories of capital ${ }^{3}$.

Additionally, although some studies used continuous variables to construct the interaction terms between monetary policy and capital (Ehrmann et al., 2003; Jimborean, 2009; Gambacorta and Marques-Ibanez, 2011; Jiménez et al., 2012), they did not exploit the benefits of continuous variables. Their approach only considered the effects of monetary restrictions on lending for a specific value of capital. However, because continuous variables can adopt infinite

\footnotetext{
${ }^{2}$ See, among others, Meh and Moran (2010), Brei et al. (2012), Francis and Osborne (2012), Shaw et al. (2013), and Ono (2015).

${ }^{3}$ For instance, Kishan and Opiela (2000; 2006) suggested that the category of "undercapitalized" banks comprises those with a capital-to-assets ratio lower than $8 \%$, whereas Altunbas et al. (2002) considered as "undercapitalized" those banks with a capital ratio below 5\%. On the other hand, Gambacorta (2005) defined the capital ratios of "poorly capitalized" and "well-capitalized" banks as below the $10^{\text {th }}$ percentile and above the $90^{\text {th }}$ percentile of the average capital ratio of the sample, respectively.
} 
values, it is possible to completely analyze the effects of monetary decisions, both restrictive and expansionary, on loan supply at any level of capital.

On the other hand, most of these studies analyze the role of capital during monetary restrictions exclusively. To our knowledge, only Kishan and Opiela (2006) investigated the effects of restrictive and expansionary monetary policies separately. However, these authors divided the monetary policy indicator into restrictive and expansionary policy stances, depending on whether the interest rates increase or decrease, respectively. The inclusion of two possible values for the monetary policy indicator (restrictive or expansionary monetary regime) does not allow analyzing the different variations of interest rates that can occur within the same monetary regime.

In this regard, this study provides a new contribution to the existing literature. We analyze how bank capital affects the loans supply reaction to both monetary contractions and expansions by including interaction terms between continuous variables (monetary policy and bank capital). In particular, we exploit the advantages of continuous variables by assessing how the marginal effects of monetary policy on the growth of loans vary with the value of capital.

This new approach provides several advantages over previous studies on this topic. First, it considerably improves the interpretation of statistical results because it exploits all the information included in the variables used to construct the interaction terms. Second, it provides a better and more precise understanding for monetary authorities and banking regulators of how capital determines the effects of monetary policy on lending during both restrictive and expansionary regimes.

\section{Empirical analysis}

\subsection{Sample}

Our sample comprises credit institutions (banks, savings banks, and cooperative banks) from 12 Eurozone countries ${ }^{4}$ over the period 1999 to 2012. The financial information on each credit institution comes from the BanksScope database, whereas the macroeconomic information comes from the World Development Indicators of the World Bank, OECD statistics, the European Central Bank, and EuroStat.

According to Favero et al. (1999), and Olivero et al. (2011), we remove from the sample those institutions that fulfill some of these conditions: 1) banks with negative values of assets, loans, deposits, interest income, and expenses; 2) banks with growth rates of loans or deposits greater than 300\%; 3) banks with loans 100 times greater than deposits; 4) banks with a marginal lending activity, defined as those with a proportion of loans over deposits lower than $10 \%$; and 5) banks with total asset variations of more than $75 \%$ in a year, which are those that have probably been involved in mergers or acquisitions.

Because we include some variables lagged one year, we use a panel of credit institutions with data available for a minimum of five consecutive years between 1999 and 2012. This condition is essential in testing for second-order serial correlations, which is carried out to ensure the robustness of the estimates obtained by System-GMM (Arellano and Bond, 1991).

Table 1 shows the number of institutions and observations from each country and the temporary distribution of the sample.

[Insert Table 1]

\footnotetext{
${ }^{4}$ The original 11 countries (Austria, Belgium, Finland, France, Germany, Ireland, Italy, Luxembourg, Netherlands, Portugal, and Spain) plus Greece.
} 


\subsection{Econometric model}

We propose the following model based on the approach of other studies (Kishan and Opiela, 2000; 2006; Altunbas et al., 2002; Gambacorta and Mistrulli, 2004). However, our study contributes to the previous approach by considering the advantages of including bank capital and monetary policy indicators as continuous variables. The interaction of these continuous variables allows exploiting all the information included in them and analyzing how the marginal effect of monetary policy on the growth of loans varies with the value of capital:

$$
\begin{gathered}
\quad \Delta \ln (\text { loans })_{i, t}=\alpha_{0}+\alpha_{1} \Delta \ln (\text { loans })_{i, t-1}+\sum_{j=0}^{1} \beta_{j} \Delta \mathrm{i}_{m, t-j}+\rho_{1} C A P_{i, t-1}+\sum_{j=0}^{1} \mu_{j} \Delta \mathrm{i}_{m, t-j} * C A P_{i, t-1}+ \\
\sum_{j=0}^{1} \epsilon_{j}\left(\Delta \mathrm{i}_{m, t-j} * C A P_{i, t-1}\right)^{2}+\rho_{2} S I Z E_{i, t-1}+\rho_{3} L I Q_{i, t-1}+\rho_{4} L L P_{i, t-1}+\sum_{j=0}^{1} \tau_{j} \Delta \mathrm{i}_{m, t-j} * S I Z E_{i, t-1}+ \\
\sum_{j=0}^{1} \theta_{j} \Delta \mathrm{i}_{m, t-j} * L I Q_{i, t-1}+\sum_{j=0}^{1} \varphi_{j} \Delta \mathrm{i}_{m, t-j} * L L P_{i, t-1}+\rho_{5} M C_{m, t}+\sum_{j=0}^{1} \omega_{j} \Delta \mathrm{i}_{m, t-j} * M C_{m, t}+\rho_{6} S R_{m, t}+ \\
\sum_{j=0}^{1} \gamma_{j} \Delta \mathrm{i}_{m, t-j} * S R_{m, t}+\sum_{j=0}^{1} \delta_{j} \Delta \ln (\mathrm{GDP})_{m, t-j}+\sum_{t=1}^{13} \pi_{t} \mathrm{Year}_{t}+\sum_{m=1}^{11} \vartheta_{m} \text { Country }_{m}+\varepsilon_{i, t}
\end{gathered}
$$

The dependent variable, $\Delta \ln (\text { Loans })_{i, t}$, is the growth rate in loan supply from bank $i$ in year $t$ relative to year $t$-1 (Ehrmann et al., 2003; Gambacorta, 2005; Jimborean, 2009; Gambacorta and Marques-Ibanez, 2011). Following previous studies, we include the growth rate of loans lagged one year $\left(\Delta \ln (\text { Loans })_{i, t-1}\right)$ as an independent variable to capture the persistence of the dependent variable.

The monetary policy indicator $\Delta i$ is measured by the change in the short-term money market rate (Ehrmann et al., 2003; Altunbas et al., 2010; Olivero et al., 2011). We include the current and lagged one-year monetary policy indicators $\left(\Delta i_{m, t}\right.$ and $\left.\Delta i_{m, t-1}\right)$ because banks may not react immediately to monetary shocks (Jimborean, 2009). We expect an increase in the money market rate to lead to a reduction in loan supply.

CAP represents the capital of banks and is the ratio of equity over assets ${ }^{5}$. Banks with higher levels of capital extend more credit; hence, this variable should have a positive coefficient (Kishan and Opiela, 2000; 2006).

We also include the interaction terms between the monetary policy indicators $\left(\Delta i_{m, t}\right.$ and $\left.\Delta i_{m, t-1}\right)$ and capital $(C A P)$ to measure the effects of capitalization on loan supply reaction to monetary policy. Less capitalized banks have more difficult access to funding; thus, their lending is more affected by monetary restrictions (Kishan and Opiela, 2000; 2006; Altunbas et al., 2002).

Previous studies suggested that the monetary policy transmission through bank capital should be different during monetary contractions and expansions (Kishan and Opiela, 2006). In this regard, more capitalized banks are less affected by monetary restrictions and benefit more from monetary expansions. To capture this different effect for banks with higher capital, we include in Equation (1) the square of the interaction terms between monetary policy and capital: $\left(\Delta i_{m, t} * C A P_{i, t-1}\right)^{2}$ and $\left(\Delta i_{m, t-1} * C A P_{i, t-1}\right)^{2}$. If such different effect exists, these variables should have a positive coefficient. Thus, when there is an increase in the short-term money market rate, the reduction in bank loans caused by a restrictive monetary policy should be less pronounced for more capitalized banks. In addition, when the short-term money market rate decreases, the increase in loan supply due to a monetary expansion should be amplified for banks with more capital $^{6}$.

\footnotetext{
5 Following previous studies, we include this variable lagged one year to avoid endogeneity bias (Gambacorta and Mistrulli, 2004; Gambacorta, 2005; Jimborean, 2009).

${ }^{6}$ Cantero-Saiz et al. (2014) introduced a similar squared interaction variable to capture asymmetric effects of the bank lending channel caused by sovereign risk.
} 
Apart from capital $(C A P)$, we also include as control variables in Equation (1) three additional bank-specific characteristics: SIZE, LIQ, and $L L P^{7}$. SIZE represents the logarithm of total assets. Normally, larger banks enjoy higher loan growth rates; thus, we expect this variable to have a positive coefficient (Kashyap and Stein, 1995; 2000). LIQ is the ratio of cash and securities over total assets. Liquid banks are more able to increase their loan supply; hence, this variable should have a positive sign (Kashyap and Stein, 2000). LLP represents the credit risk of a bank and is measured by the proportion of loan-loss-provisions over total loans. Banks with higher credit risk have lower loan growth rates; thus, we expect a negative sign for this variable (Altunbas et al., 2010; Gambacorta and Marques-Ibanez, 2011).

We also include the interaction terms between the monetary policy indicators $\left(\Delta i_{m, t}\right.$ and $\left.\Delta i_{m, t-1}\right)$ and these three bank-specific characteristics (SIZE, LIQ, and $L L P$ ) to measure the effects of these specific characteristics on lending reaction to monetary policy. First, several studies found that smaller banks are more sensitive to monetary contractions (Kashyap and Stein, 1995; 2000; Kishan and Opiela, 2000). Second, most studies indicated that more liquid banks are less sensitive to monetary shocks because they can more easily avoid the reduction in bank lending caused by monetary contractions through their liquid assets (Kashyap and Stein, 2000; Ehrmann et al., 2003; Gambacorta, 2005). Third, banks with higher credit risk reduce their loan supply more under monetary restrictions (Altunbas et al., 2010; Gambacorta and Marques-Ibanez, 2011).

We use continuous variables to construct the previous interaction terms between monetary policy and the four bank-specific characteristics (CAP, SIZE, LIQ, and LLP). To interpret these interactions properly, the bank-specific characteristics are normalized with respect to their means across all the banks in the sample ${ }^{8}$.

$$
\begin{gathered}
C A P_{i t}=\frac{E_{i t}}{A_{i t}}-\frac{\sum_{t=1}^{T}\left(\sum_{i=1}^{N}\left(E_{i t} / A_{i t}\right) / N_{t}\right)}{T} \\
S I Z E_{i t}=\log A_{i t}-\frac{\sum_{i=1}^{N} \log A_{i t}}{N_{t}} \\
L I Q_{i t}=\frac{L_{i t}}{A_{i t}}-\frac{\sum_{t=1}^{T}\left(\sum_{i=1}^{N}\left(L_{i t} / A_{i t}\right) / N_{t}\right)}{T} \\
L L P_{i t}=\frac{P_{i t}}{\text { Loans }_{i t}}-\frac{\sum_{t=1}^{T}\left(\sum_{i=1}^{N}\left(P_{i t} / \text { Loans }_{i t}\right) / N_{t}\right)}{T}
\end{gathered}
$$

$E_{i t}$ is total equity, $A_{i t}$ denotes total assets, $L_{i t}$ refers to securities and cash due from banks, $P_{i t}$ indicates loan-loss-provisions, Loans $i t$ is total loans, and $N_{t}$ is the number of banks.

The normalization implies that in Equation (1), the mean of the interaction terms is zero, and the parameters $\beta_{j}$ are interpreted as the average effect of monetary policy on loan supply growth. The coefficients of the bank-specific characteristics $\left(\rho_{j} ; \mathrm{j}: 1, . ., 4\right)$ describe the effects that these characteristics have on the growth of loans when the change in the short-term money market rates $\left(\Delta i_{m, t}\right.$ and $\left.\Delta i_{m, t-1}\right)$ is zero. The coefficients of the interaction terms $\left(\mu_{j}, \tau_{j}, \theta_{j}, \varphi_{j}\right)$ show whether the bank-specific characteristics affect the way loan supply reacts to monetary shocks.

Finally, we introduce three macroeconomic indicators as control variables: $M C, S R$, and $\Delta \ln (G D P)) . M C$ refers to market concentration. We use the Herfindahl Index in terms of assets obtained from the European Central Bank (ECB). We interact this variable with the monetary

\footnotetext{
${ }^{7}$ As in the case of capital $(C A P)$, these three bank-specific characteristics are lagged one year to avoid endogeneity problems (Kashyap and Stein, 1995; 2000; Ehrmann et al., 2003).

${ }^{8}$ Many previous studies applied the same approach (Ehrmann et al., 2003; Gambacorta, 2005; Jimborean, 2009).
} 
policy indicators $\left(\Delta i_{m, t}\right.$ and $\left.\Delta i_{m, t-1}\right)$. Previous studies showed that there is a positive relationship between these interactions and loan supply growth (Adams and Amel, 2011; Olivero et al., 2011).

$S R$ denotes sovereign risk, which we calculate as the risk premium of a country relative to Germany. Recently, Cantero-Saiz et al. (2014) showed that banks operating in countries with higher sovereign risk are more sensitive to monetary restrictions. We also include the interaction terms between this variable and the monetary policy indicators $\left(\Delta i_{m, t}\right.$ and $\left.\Delta i_{m, t-1}\right)$.

The variable $\Delta \ln (G D P)$ measures the nominal gross domestic product (GDP) growth rate and controls for loan demand. Better economic conditions increase profitable investment projects, which boost the demand for bank credit. Several studies found that GDP growth impulses loan supply (Gambacorta, 2005; Jimborean, 2009; Altunbas et al., 2010). Thus, we expect a positive coefficient for this variable.

Country and year dummies are included as control variables. $\varepsilon_{\mathrm{i}, \mathrm{t}}$ is the error term. $i=1$, $2, \ldots, N$ refers to a specific bank $i ; m=1,2, \ldots, M$ indicates a particular country $m ; t=1,2, \ldots, T$ indicates a specific year $t$; and $j$ denotes the number of lags.

Table 2 provides a summary of the independent variables and their expected relationship with the dependent variable. Table 3 shows the descriptive statistics of the variables included in the analysis. Table 4 presents the correlations between the variables to identify potential collinearity problems.

\section{[Insert Tables 2, 3 \& 4]}

The model proposed in Equation (1) is estimated by using the two-step System-GMM methodology on dynamic panel data. This allows controlling for endogeneity problems and obtaining consistent and unbiased estimates by using lagged independent variables as instruments (Arellano and Bond, 1991). Bank-specific characteristics and their interactions with monetary policy are considered to be endogenous, whereas macroeconomic variables are exogenous (Jimborean, 2009; Cantero-Saiz et al., 2014). We follow an estimation strategy that uses between the second and the fourth lag as instruments.

\subsection{Results and discussion}

Table 5 shows the analysis results. In model (a), we include the variables most commonly used in previous studies: capital $(C A P)$, size $(S I Z E)$, liquidity $(L I Q)$, credit risk $(L L P)$, and market concentration $(M C)$. In model (b), we add the variable $S R$ to control for sovereign risk; and in model (c), we control for structural breaks caused by the crisis.

\section{[Insert Table 5]}

In model (a), the monetary policy indicator $(\Delta i)$ has the expected negative sign but only for the current variable. Consequently, an increase in the short-term money market rate leads to an immediate reduction in bank loans. As we have proposed, the quadratic interaction between capital $(C A P)$ and current monetary policy is positive and significant. However, because we are dealing with the interaction of two continuous variables (monetary policy and capital), the marginal effect of monetary policy on the growth of loans will depend on the value of capital. To capture this marginal effect, we have to take the derivative of Equation (1) with respect to monetary policy ${ }^{9}$ :

\footnotetext{
${ }^{9}$ Note that the variable $S R$ does not appear in Equation (2) because it is not included in model (a).
} 


$$
\begin{aligned}
& \quad \frac{\partial \Delta \ln (\text { loans })_{i, t}}{\partial \Delta \mathrm{i}_{m, t}}=\beta_{0}+\mu_{0} C A P_{i, t-1}+2 \epsilon_{0} \Delta \mathrm{i}_{m, t}\left(C A P_{i, t-1}\right)^{2}+\tau_{0} S I Z E_{i, t-1}+\theta_{0} L I Q_{i, t-1}+ \\
& \varphi_{0} L L P_{i, t-1}+\omega_{0} M C_{m, t}
\end{aligned}
$$

Because the variables SIZE, $L I Q$, and $L L P$ are normalized with respect to their means, the marginal effect for an average bank is:

$$
\frac{\partial \Delta \ln (\text { loans })_{i, t}}{\partial \Delta \mathrm{i}_{m, t}}=\beta_{0}+\mu_{0} C A P_{i, t-1}+2 \epsilon_{0} \Delta \mathrm{i}_{m, t}\left(C A P_{i, t-1}\right)^{2}+\omega_{0} M C_{m, t}
$$

The marginal effect in Equation (3) depends on the monetary policy variable, thus this marginal effect will vary depending on the different values of the monetary policy indicator. Therefore, we estimate the marginal effects for an average bank in two different scenarios: a $0.75 \%$ increase and a $0.75 \%$ decrease in the monetary policy variable (short-term money market rate). We choose this percentage because it is the closest multiple of $0.25 \%$ to the mean annual increase/decrease in the short-term money market rate from 1999 to $2012^{10}$. In addition, because the variable $M C$ is not normalized, to calculate the marginal effect, we replace $M C$ with the median of the countries in the sample. The marginal effect also changes with the level of capital $(C A P)$. The measure of this marginal effect is the main purpose of this article, so that we check how the effects of monetary policy on lending vary along all the possible values that our capital variable $(C A P)$ adopt, as opposed to previous studies which only considered these effects at specific values of bank capital. Since our capital variable $(C A P)$ can adopt infinite values, we need to construct plots to interpret the results properly.

Figure 1 shows the marginal effect of monetary policy on the growth of loans in relation to the normalized capital with respect to the mean ${ }^{11}$ when the short-term money market rate increases by $0.75 \%$. The dotted lines represent the $90 \%$ confidence interval ${ }^{12}$. Confidence intervals of $90 \%$ allow us to determine the conditions under which monetary policy has a statistically significant effect on the growth of loans (whenever both upper and lower bounds of the $90 \%$ confidence interval are either above or below zero). An increase in the short-term money market rate leads to a reduction in lending for banks whose normalized capital with respect to the mean is below 0.6973 ( 0.7827 without normalization). In this interval, the marginal effect on bank loans is similar (between -0.1565 and -0.1652). For a capital-to-assets ratio of 0.7827 or higher, the marginal effect is not significant because the upper bound of the $90 \%$ confidence interval is above zero, whereas the lower bound is below zero. Therefore, there is no evidence in our sample that these highly capitalized banks reduce their loan supply during monetary restrictions. However, we should bear in mind that these banks represent only $0.16 \%$ of our sample, which is why we conclude that, in general, capital does not lead to large differences in loan supply reaction to monetary restrictions. The results with the new approach presented in this article differ from those of previous studies, which suggested that more poorly capitalized banks are more sensitive to monetary contractions (Altunbas et al., 2002; Kishan and Opiela, 2000; 2006; Gambacorta and Mistrulli, 2004; Gambacorta, 2005; Jiménez et al., 2012). Greater uncertainty, funding restrictions, and risk aversion in the crisis years probably lead banks to keep more capital for precautionary purposes instead of lending it out, which is why

\footnotetext{
${ }^{10}$ We chose multiples of $0.25 \%$ because the ECB adjusts its target rates using these multiples during our sample period. We also estimated the marginal effect by using different increases/decreases in the shortterm money market rate. We started from the minimum rate variation in our sample and added $0.25 \%$ to the previous value until we reached the maximum variation in our sample. The results are similar to the $0.75 \%$ increase/decrease reported in this article but are intensified as the variation in interest rates increases. These findings are not included but are available on request.

${ }^{11}$ As we mentioned previously, the variable $C A P$ is normalized with respect to the mean in Equation (1), similarly to the other bank-specific characteristics (SIZE, LIQ, and $L L P$ ).

${ }^{12}$ We follow Aiken and West (1991) in computing the confidence intervals.
} 
highly capitalized banks do not show a lower decrease in loan supply during monetary contractions.

\section{[Insert Figure 1]}

Figure 2 shows the marginal effect of monetary policy on the growth of loans in relation to the normalized capital when the short-term money market rate decreases by $0.75 \%$. In this scenario, we must interpret the marginal effect carefully. Because we are assessing the effect of a decrease in the interest rate, if the marginal effect is positive, a reduction in the interest rate will have the opposite sign (negative), and vice versa. Figure 2 shows that the positive effect on lending of a reduction in the short-term money market rate is lower for banks with low levels of capital. The positive effect has its minimum (0.1675) when the level of normalized capital with respect to the mean is -0.0827 ( 0.0027 without normalization). However, when the level of capital increases, this positive effect becomes larger. The marginal effect reaches a maximum (0.3582) when the level of normalized capital is equal to 0.8173 ( 0.9027 without normalization). Therefore, banks benefit more from monetary expansions as they become better capitalized. An expansionary monetary policy alleviates financial frictions and improves balance sheets; hence, banks with a larger capital base can increase their loan supply more compared with those that have poor levels of capital.

\section{[Insert Figure 2]}

Regarding the control variables, the variable $L L P$ and its interaction with lagged monetary policy are negative and significant. Therefore, the lending growth of banks with higher credit risk is more sensitive to monetary contractions. The interaction between $M C$ and current monetary policy is significant with a positive coefficient; therefore, banks that operate in more concentrated markets can better insulate their lending from monetary shocks. Finally, the variable $\Delta \ln (G D P)$ is significant with a positive coefficient; thus, an increase in the GDP growth impulses bank lending.

In the last few years, as the crisis has worsened, sovereign risk has become an important determinant of the ability of banks to provide lending (Cantero-Saiz, et al., 2014). Thus, in Table 5, we add the variable $S R$ to model (b) to control for the sovereign risk of the countries where banks operate. In addition, the onset of the financial crisis in 2008 supposed severe financial restrictions for banks and led them to curtail lending. To control for structural breaks caused by the crisis, we estimate model (b), adding the interaction term between the capital $(C A P)$ and a dummy variable $P C_{t}$. This dummy takes the value of 1 for the years 1999 to 2007 and 0 otherwise; therefore, it represents the years before the outbreak of the crisis. The results of these models are similar to those of model (a). Besides, the marginal effects of monetary policy on the growth of loans in relation to the normalized capital based in these models are similar to those reported previously (see Figures 1 and 2) ${ }^{13}$.

\section{Conclusions}

The role of bank capital in the transmission of monetary policy has received special attention in the last years due to the ability of such capital to maintain lending during the crisis and the changes in the banking industry following new regulations on capital adequacy requirements. This study analyzes how bank capital determines the effects of monetary policy on loan supply during restrictive and expansionary regimes. Previous studies about this topic in general have shown that lending from lower capitalized banks is more affected by monetary restrictions and that such banks benefit less from monetary expansions (Kishan and Opiela, 2000; 2006; Altunbas et al., 2002; Van den Heuvel, 2002; 2012; Gambacorta, 2005; Jiménez et al., 2012). However, these studies either focused on an empirical specification that considers capital and monetary policy indicators as categorical variables or, although some used

\footnotetext{
${ }^{13}$ The Figures of the marginal effects of monetary policy on loan supply growth in relation to the normalized capital based in models (b) and (c) are not shown in the article, but are available on request.
} 
continuous variables, did not consider the advantages of these variables. Thus, this approach does not allow exploiting all the information included in the variables and provides a narrow interpretation of the results. This article provides a new contribution to the existing literature because it exploits the advantages of including interaction terms between continuous variables. In particular, we analyze how the marginal effects of monetary policy on loan supply vary with the level of capital. This new focus supposes an improvement in the interpretation of statistical results compared with previous studies and allows a more detailed understanding of how bank capital determines lending reaction to monetary shocks.

By using a sample of European banks over the period 1999 to 2012, we show that the negative effects of monetary restrictions on loan supply are similar across banks, regardless of their capitalization. However, better capitalized banks benefit more from monetary expansions because they proportionally increase lending to a greater extent compared with those that have lower levels of capital.

These results are very interesting for capital regulations and for the way monetary policy is carried out in Europe. Contrary to previous studies, our findings indicate that capital only leads to significant differences in the monetary policy transmission during monetary expansions. This suggests that expansionary monetary policies aimed at recovering credit during the crisis would be more effective if banking systems were well capitalized. In contrast, monetary restrictions would affect loan supply in the same way regardless of the amount of capital held by banks. Funding difficulties, risk aversion, and uncertainty during the crisis may force banks to maintain more precautionary capital, especially when monetary conditions are more restrictive, which is why better capitalized banks do not experience a lower reduction in loan supply. However, because monetary expansions alleviate financial frictions and reduce financing costs, banks with higher capital are able to increase their lending to a greater extent.

The main implications of these findings are that strengthen capital requirements can be important for the ECB to achieve not only its supervisory objective, but also its monetary policy objective. Higher capital base is essential for the soundness of the financial system, which serves the supervisory objective of the ECB. Besides, our study shows that this higher level of capital allows monetary expansions of the ECB to have a more powerful effect on loans and to stabilize the credit cycle. This article has tried to shed light on the effects of bank capital on the transmission of monetary policy through loan supply. However, further research is needed to fully understand the role of capital in the monetary policy transmission and in the new regulatory environment. On one hand, since banks act as both lenders and borrowers, it would be interesting to use the methodology shown in this article to quantify how capital determines the effects of monetary shocks on the cost of debt funding for banks. On the other hand, it could be quantified how changes in capital requirements affect the supply of lending.

\section{Acknowledgements}

This work was supported by the University of Cantabria Foundation for Education and Research in the Financial Sector (UCEIF Foundation).

\section{References}

Adams, R.M. and Amel, D.F. (2011): Market structure and the pass-through of the federal funds rate. Journal of Banking and Finance, 35 (5), 1087-1096.

Aiken, L.S. and West, S.G. (1991): Multiple regression: Testing and interpreting interactions. Sage Publications, Incorporated.

Altunbas, Y., Fazylov, O. and Molyneux, P. (2002): Evidence on the bank lending channel in Europe. Journal of Banking and Finance, 26 (11), 2093-2110.

Altunbas, Y., Gambacorta, L. and Marques-Ibanez, D. (2010): Bank risk and monetary policy. Journal of Financial Stability, 6 (3), 121-129.

Arellano, M. and Bond, S. (1991): Some tests of specification for panel data: Monte Carlo evidence and an application to employment equations. Review of Economic Studies, 58 (2), 277-297. 
Bernanke, B.S. and Blinder, A.S. (1988): Credit, money and aggregate demand. The American Economic Review, 78 (2), 435-439.

Bolton, P. and Freixas, X. (2006): Corporate finance and the monetary transmission mechanism. Review of Financial Studies, 19 (3), 829-870.

Brei, M., Gambacorta, L. and von Peter, G. (2012): Rescue packages and bank lending. Journal of Banking and Finance, 37 (2), 490-505.

Cantero-Saiz, M., Sanfilippo-Azofra, S., Torre-Olmo, B. and Lopez-Gutierrez, C. (2014): Sovereign risk and the bank lending channel in Europe. Journal of International Money and Finance, 47, 1-20.

Disyatat, P. (2011): The bank lending channel revisited. Journal of Money, Credit and Banking, 43 (4), 711-734.

Ehrmann, M., Gambacorta, L., Martínez-Pagés, J., Sevestre, P. and Worms, A. (2003): Financial systems and the role of banks in monetary policy transmission in the Euro Area. In: Angeloni, I., Kashyap, A., Mojon, B. (Eds.), Monetary policy transmission in the Euro Area. Cambridge University Press, Cambridge, 235-269.

Favero, C.A., Giavazzi, F. and Flabbi, L. (1999): The transmission mechanism of monetary policy in Europe: evidence from banks' balance sheets. National Bureau of Economic Research, ( ${ }^{\circ}$ w7231).

Francis, W.B. and Osborne, M. (2012): Capital requirements and bank behavior in the UK: are lessons for international capital standards? Journal of Banking and Finance, 36, 803816.

Gambacorta, L. (2005): Inside the bank lending channel. European Economic Review, 49 (7), 1737-1759.

Gambacorta, L. and Marques-Ibanez, D. (2011): The bank lending channel: lessons from the crisis. Economic Policy, 26 (66), 135-182.

Gambacorta, L. and Mistrulli, P.E. (2004): Does bank capital affect lending behavior? Journal of Financial Intermediation, 13(4), 436-57.

Gibson, M.S. (1997): The bank lending channel of monetary policy transmission: evidence from a model of bank behavior that incorporates long-term customer relationships. Board of Governors of the Federal Reserve System. International Finance Discussion Papers, (No. 584).

Jayaratne, J. and Morgan, D.P. (2000): Capital market frictions and deposit constraints at banks. Journal of Money, Credit and Banking, 32 (1), 74-92.

Jimborean, R. (2009): The role of banks in the monetary policy transmission in the new EU member states. Economic Systems, 33 (4), 360-375.

Jiménez, G., Ongena, S., Peydro, J.L. and Saurina, J. (2012): Credit supply and monetary policy: Identifying the bank balance-sheet channel with loan applications. The American Economic Review, 102 (5), 2301-2326.

Kashyap, A.K., and Stein, J.C. (1995): The impact of monetary policy on bank balance sheets. Carnegie-Rochester Conference Series on Public Policy, 42, 151-195.

Kashyap, A.K., and Stein, J.C. (2000): What do a million observations on banks say about the transmission of monetary policy? The American Economic Review, 90 (3), 407-428.

Kishan, R.P. and Opiela, T.P. (2000): Bank size, bank capital and the bank lending channel. Journal of Money, Credit and Banking, 32 (1), 121-141.

Kishan, R.P. and Opiela, T.P. (2006): Bank capital and loan asymmetry in the transmission of monetary policy. Journal of Banking and Finance, 30 (1), 259- 285.

Maddaloni, A., and Peydro, J.L. (2011): Bank Risk-Taking, Securitization, Supervision and Low Interest Rates: Evidence from the Euro Area and U.S. Lending Standards. Review of Financial Studies, 24(6), 2121-165

Meh, C.A. and Moran, K. (2010): The role of bank capital in the propagation shocks. Journal of Economic Dynamics and Control, 34, 555-576.

Olivero, M.P., Li, Y. and Jeon, B.N. (2011): Consolidation in banking and the lending channel: Evidence from bank-level data in Asia and Latin America. Journal of International Money and Finance, 30 (6) 1034-1054. 
Ono, S. (2015): Bank lending channel in monetary policy transmission: evidence from Russia. International Journal of Economics and Finance, 7 (4), 1-11.

Peek, J. and Rosengren, E.S. (1995): Bank lending and the transmission of monetary policy. In Conference series-Federal Reserve Bank of Boston. Federal Reserve Bank of Boston, 47-68.

Shaw, M., Chang, J. and Chen, H. (2013): Capital adequacy and the bank lending channel: Macroeconomic implications. Journal of Macroeconomics, 36, 121-137.

Van den Heuvel, S.J. (2002): Does bank capital matter for monetary transmission? Economic Policy Review, 8 (1), 259-265.

Van den Heuvel, S.J. (2012): Banking conditions and the effects of monetary policy: evidence from US states. The B.E. Journal of Macroeconomics, 12 (2), 1-31.

Tables and Figures

TABLE 1: SAMPLE

\begin{tabular}{|c|c|c|c|c|c|c|c|c|c|c|c|c|c|c|c|}
\hline \multicolumn{16}{|c|}{ PANEL A: NUMBER OF BANKS PER COUNTRY } \\
\hline & & & \multicolumn{8}{|c|}{ Number of observations } & \multicolumn{5}{|c|}{ Number of banks } \\
\hline \multicolumn{3}{|c|}{ Austria } & \multicolumn{8}{|c|}{2,136} & \multicolumn{5}{|c|}{229} \\
\hline \multicolumn{3}{|c|}{ Belgium } & \multicolumn{8}{|c|}{283} & \multicolumn{5}{|c|}{38} \\
\hline \multicolumn{3}{|c|}{ Finland } & \multicolumn{8}{|c|}{35} & \multicolumn{5}{|c|}{6} \\
\hline \multicolumn{3}{|c|}{ France } & \multicolumn{8}{|c|}{1,703} & \multicolumn{5}{|c|}{221} \\
\hline \multicolumn{3}{|c|}{ Germany } & \multicolumn{8}{|c|}{18,109} & \multicolumn{5}{|c|}{1,753} \\
\hline \multicolumn{3}{|c|}{ Greece } & \multicolumn{8}{|c|}{99} & \multicolumn{5}{|c|}{17} \\
\hline \multicolumn{3}{|c|}{ Ireland } & \multicolumn{8}{|c|}{74} & \multicolumn{5}{|c|}{13} \\
\hline \multicolumn{3}{|c|}{ Italy } & \multicolumn{8}{|c|}{3,014} & \multicolumn{5}{|c|}{532} \\
\hline \multicolumn{3}{|c|}{ Luxembourg } & \multicolumn{8}{|c|}{328} & \multicolumn{5}{|c|}{48} \\
\hline \multicolumn{3}{|c|}{ Netherlands } & \multicolumn{8}{|c|}{166} & & & 28 & & \\
\hline & Portuga & & & & & 12 & 25 & & & & & & 23 & & \\
\hline & Spain & & & & & 65 & & & & & & & 120 & & \\
\hline & Total & & & & & 26,7 & 725 & & & & & & 3,028 & & \\
\hline PANEL & B: TEM & $\overline{\text { PORA }}$ & RY DIS & STRIBL & JTION & OF TH & IE SAM & IPLE & & & & & & & \\
\hline & 1999 & 2000 & 2001 & 2002 & 2003 & 2004 & 2005 & 2006 & 2007 & 2008 & 2009 & 2010 & 2011 & 2012 & $\begin{array}{l}\text { Total } \\
\text { Obs. }\end{array}$ \\
\hline $\begin{array}{l}\text { N. of } \\
\text { banks }\end{array}$ & 1,292 & 1,436 & 1.505 & 1570 & 1555 & 1557 & 1570 & 70 & 520 & 2,533 & 2.523 & 2,455 & 2,379 & 2,118 & 26,725 \\
\hline
\end{tabular}

TABLE 2: SUMMARY OF THE INDEPENDENT VARIABLES

\begin{tabular}{|c|c|c|}
\hline Variable & Description & $\begin{array}{l}\text { Expected relationship with } \\
\text { loan supply growth }\end{array}$ \\
\hline$\Delta \ln (\text { Loans })_{\mathrm{i}, \mathrm{t}-1}$ & Growth rate of loans lagged one year & Positive/ Negative \\
\hline$\Delta \mathrm{i}$ & Monetary policy: change in the short-term money market rate & Negative \\
\hline CAP & Capital: ratio of equity over total assets & Positive \\
\hline$\Delta \mathrm{i}^{*} \mathrm{CAP}$ & Linear interaction between monetary policy and capital & Positive \\
\hline SIZE & Size: logarithm of total assets & Positive \\
\hline$\triangle \mathrm{i} * \mathrm{SIZE}$ & Interaction between monetary policy and size & Positive \\
\hline LIQ & Liquidity: ratio of cash and securities over total assets & Positive \\
\hline$\Delta \mathrm{i} * \mathrm{LIQ}$ & Interaction between monetary policy and liquidity & Positive \\
\hline LLP & Credit risk: loan loss provisions over total loans & Negative \\
\hline SR & Sovereign risk: risk premium of a country relative to Germany & Negative \\
\hline$\Delta \mathrm{i} * \mathrm{SR}$ & Interaction between monetary policy and sovereign risk & Negative \\
\hline$\Delta \ln (\mathrm{GDP})$ & Gross Domestic Product growth rate & Positive \\
\hline
\end{tabular}


TABLE 3: SAMPLE STATISTICS

\begin{tabular}{|c|c|c|c|c|}
\hline Variable & Mean & Standard deviation & Minimum & Maximum \\
\hline$\Delta \ln ($ loans $)$ & 0.0290 & 0.1419 & -1.8127 & 1.2901 \\
$\Delta \ln (\mathrm{GDP})$ & 0.0339 & 0.0872 & -0.1670 & 0.2780 \\
$\Delta \mathrm{i}$ & -0.2454 & 1.2532 & -3.4059 & 1.4418 \\
$\mathrm{SIZE}$ & 13.6421 & 1.6650 & 9.1551 & 21.6704 \\
$\mathrm{LIQ}$ & 0.2394 & 0.1274 & 0.0000 & 0.8619 \\
$\mathrm{CAP}$ & 0.0854 & 0.0499 & 0.0008 & 0.9704 \\
$\mathrm{LLP}$ & 0.0072 & 0.0123 & -0.2466 & 0.3906 \\
$\mathrm{SR}$ & 0.2902 & 0.9021 & -1.1954 & 21.0025 \\
$\mathrm{MC}$ & 0.0320 & 0.0280 & 0.0140 & 0.3700 \\
\hline
\end{tabular}

The statistics of the variables SIZE, LIQ, CAP and LLP are calculated before the normalization to show more comprehensive information.

TABLE 4: CORRELATIONS

\begin{tabular}{|c|c|c|c|c|c|c|c|c|}
\hline & $\Delta \ln ($ GDP $)$ & $\Delta \mathrm{i}$ & SIZE & LIQ & CAP & LLP & SR & $\mathrm{MC}$ \\
\hline$\Delta \ln ($ GDP $)$ & 1 & & & & & & & \\
\hline$\Delta \mathrm{i}$ & 0.3981 & 1 & & & & & & \\
\hline SIZE & -0.0095 & -0.0144 & 1 & & & & & \\
\hline LIQ & -0.0032 & 0.0321 & 0.0003 & 1 & & & & \\
\hline CAP & -0.0154 & -0.0244 & -0.1462 & -0.1543 & 1 & & & \\
\hline LLP & 0.1010 & -0.0131 & -0.0472 & 0.0517 & 0.0178 & 1 & & \\
\hline SR & -0.1898 & -0.0713 & 0.0776 & -0.1372 & 0.2596 & 0.0628 & 1 & \\
\hline MC & 0.0070 & -0.0130 & 0.2789 & -0.1147 & 0.1832 & -0.0556 & 0.2710 & 1 \\
\hline
\end{tabular}

TABLE 5: RESULTS

\begin{tabular}{|c|c|c|c|c|c|c|}
\hline & (a) & & (b) & & (c) & \\
\hline$\Delta \ln (\text { loans })_{\mathrm{t}-1}$ & $0.1402(1.50)$ & & $0.1056(1.33)$ & & $0.0872(1.09)$ & \\
\hline$\Delta \ln (\mathrm{GDP})_{\mathrm{t}}$ & $1.7405(2.94)$ & $* * *$ & $0.8034(1.32)$ & & $0.8648(1.30)$ & \\
\hline$\Delta \ln (\mathrm{GDP})_{\mathrm{t}-1}$ & $0.7448(1.41)$ & & $-0.3867(-1.11)$ & & $-0.5210(-1.21)$ & \\
\hline$\Delta \mathrm{i}_{\mathrm{t}}$ & $-0.1890(-1.92)$ & $*$ & $-0.1057(-2.32)$ & $* *$ & $-0.1137(-2.22)$ & $* *$ \\
\hline$\Delta \mathrm{i}_{\mathrm{t}-1}$ & $-0.0241(-0.77)$ & & $0.0849(1.54)$ & & $0.0983(1.57)$ & \\
\hline $\mathrm{CAP}_{\mathrm{t}-1}$ & $-0.0884(-1.26)$ & & $-0.0466(-0.73)$ & & $-0.0445(-0.49)$ & \\
\hline$\Delta \mathrm{i}_{\mathrm{t}} * \mathrm{CAP}_{\mathrm{t}-1}$ & $0.0600(1.62)$ & & $0.0511(1.67)$ & $*$ & $0.0529(1.59)$ & \\
\hline$\Delta \mathrm{i}_{\mathrm{t}-1} * \mathrm{CAP}_{\mathrm{t}-1}$ & $0.0104(0.26)$ & & $-0.0166(-0.57)$ & & $-0.0040(-0.14)$ & \\
\hline$\left(\Delta \mathrm{i}_{\mathrm{t}} * \mathrm{CAP}_{\mathrm{t}-1}\right)^{2}$ & $0.1112(2.87)$ & $* * *$ & $0.0988(2.40)$ & $* *$ & $0.0889(2.24)$ & $* *$ \\
\hline$\left(\Delta \mathrm{i}_{\mathrm{t}-1} * \mathrm{CAP}_{\mathrm{t}-1}\right)^{2}$ & $0.0102(0.38)$ & & $-0.0069(-0.32)$ & & $0.0037(0.17)$ & \\
\hline $\mathrm{CAP}_{\mathrm{t}-1} * \mathrm{PC}_{\mathrm{t}}$ & & & & & $-0.0155(-0.18)$ & \\
\hline SIZE $_{t-1}$ & $-0.0003(-0.19)$ & & $0.0003(0.22)$ & & $-0.0008(-0.50)$ & \\
\hline $\mathrm{LIQ}_{\mathrm{t}-1}$ & $0.0191(0.51)$ & & $0.0503(2.62)$ & $* * *$ & $0.0461(2.14)$ & $* *$ \\
\hline $\operatorname{LLP}_{t-1}$ & $-1.1660(-1.80)$ & $*$ & $-1.0602(-1.88)$ & $*$ & $-0.9686(-1.63)$ & \\
\hline$\Delta \mathrm{i}_{\mathrm{t}} * \operatorname{SIZE}_{\mathrm{t}-1}$ & $0.0005(0.90)$ & & $0.0001(0.22)$ & & $0.0003(0.56)$ & \\
\hline$\Delta \mathrm{i}_{\mathrm{t}-1} * \mathrm{SIZE}_{\mathrm{t}-1}$ & $0.0001(0.14)$ & & $-0.0001(-0.21)$ & & $0.0000(0.07)$ & \\
\hline$\Delta \mathrm{i}_{\mathrm{t}} * \mathrm{LIQ}_{\mathrm{t}-1}$ & $-0.0065(-0.95)$ & & $-0.0109(-1.49)$ & & $-0.0110(-1.51)$ & \\
\hline$\Delta \mathrm{i}_{\mathrm{t}-1} * \mathrm{LIQ}_{\mathrm{t}-1}$ & $0.0024(0.39)$ & & $-0.0083(-1.44)$ & & $-0.0062(-1.11)$ & \\
\hline$\Delta \mathrm{i}_{\mathrm{t}} * \mathrm{LLP}_{\mathrm{t}-1}$ & $-0.3724(-1.19)$ & & $-0.1426(-0.68)$ & & $-0.1061(-0.49)$ & \\
\hline$\Delta \mathrm{i}_{\mathrm{t}-1} * \mathrm{LLP}_{\mathrm{t}-1}$ & $-0.8810(-2.44)$ & $* *$ & $-0.1210(-0.48)$ & & $-0.1712(-0.69)$ & \\
\hline $\mathrm{MC}_{\mathrm{t}}$ & $-0.4531(-0.88)$ & & $0.3514(0.77)$ & & $0.5862(1.26)$ & \\
\hline$\Delta \mathrm{i}_{\mathrm{t}} * \mathrm{MC}_{\mathrm{t}}$ & $0.2491(2.60)$ & $* * *$ & $0.3816(3.39)$ & $* * *$ & $0.3726(3.59)$ & $* * *$ \\
\hline$\Delta \mathrm{i}_{\mathrm{t}-1} * \mathrm{MC}_{\mathrm{t}}$ & $0.0047(0.05)$ & & $0.0152(0.31)$ & & $0.0141(0.27)$ & \\
\hline $\mathrm{SR}_{\mathrm{t}}$ & & & $-0.0276(-4.35)$ & $* * *$ & $-0.0280(-4.35)$ & $* * *$ \\
\hline$\Delta \mathrm{i}_{\mathrm{t}} * \mathrm{SR}_{\mathrm{t}}$ & & & $-0.0058(-2.75)$ & $* * *$ & $-0.0065(-2.94)$ & $* * *$ \\
\hline$\Delta \mathrm{i}_{\mathrm{t}-1} * \mathrm{SR}_{\mathrm{t}}$ & & & $-0.0010(-0.37)$ & & $-0.0021(-0.71)$ & \\
\hline CONS & $-0.1465(-3.67)$ & $* * *$ & $-0.1324(-5.28)$ & $* * *$ & $-0.1384(-4.95)$ & $* * *$ \\
\hline Country dummies & Yes & & Yes & & Yes & \\
\hline Year dummies & Yes & & Yes & & Yes & \\
\hline Linear test & & & & & $-0.0599(-1.01)$ & \\
\hline $\mathrm{m}_{2}$ & 0.246 & & 0.352 & & 0.443 & \\
\hline Hansen & 0.313 & & 0.158 & & 0.182 & \\
\hline
\end{tabular}

Coefficients associated with each variable. In brackets, T-student; *** indicates a level of significance of 0.01 , ** indicates a level of significance of 0.05 , * indicates a level of significance of $0.1 ; \mathrm{m}_{2}$ is the p-value of the 2 nd order serial correlation statistic. Linear test is the linear restriction test of the sum of the coefficients associated with CAP and $\mathrm{CAP} * \mathrm{PCt}$. Hansen is the p-value of the over-identifying restriction test. 


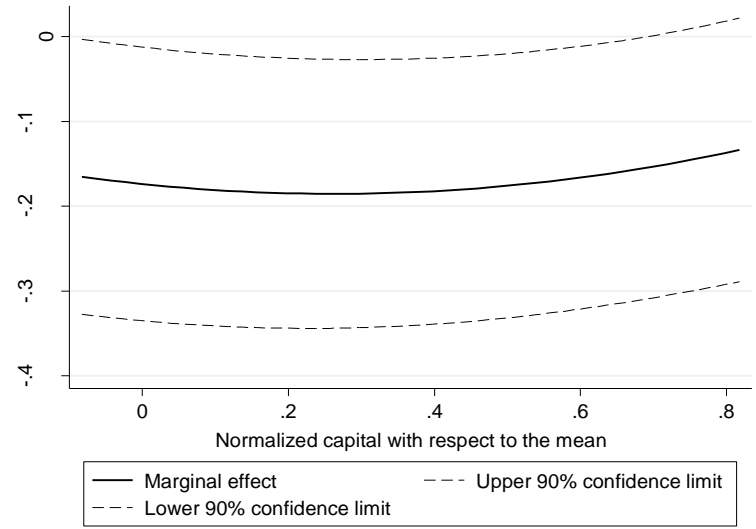

Fig. 1. Marginal effect of monetary policy on the growth of loans in relation to capital when short-term money market rate increases by $0.75 \%$. Based on model (a), Table 5.

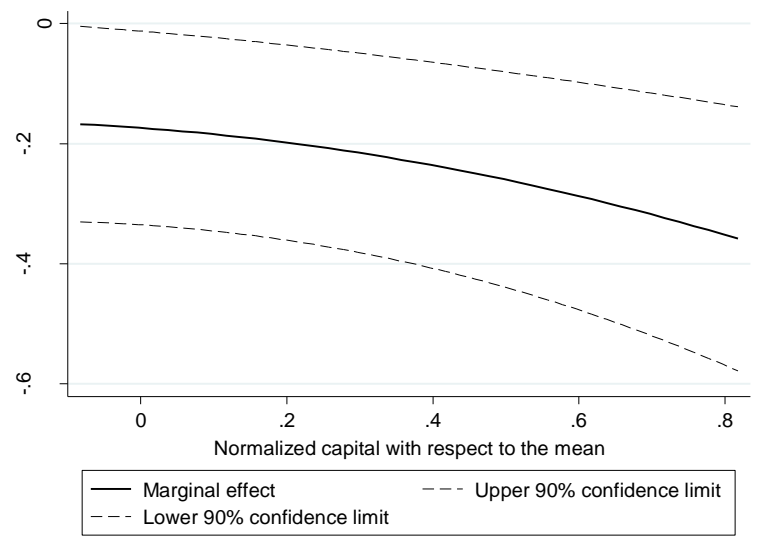

Fig. 2. Marginal effect of monetary policy on the growth of loans in relation to capital when short-term money market rate decreases by $0.75 \%$. Based on model (a), Table 5 